Caligrama, Belo Horizonte, v. 23, n. 1, p. 21-38, 2018

\title{
Trajetórias e paisagens de exílio na narrativa de Primo Levi
}

\section{Trajectories and landscapes of exile in Primo Levi literature}

\author{
Anna Basevi ${ }^{1}$ \\ Universidade do Estado do Rio de Janeiro, Rio de Janeiro, Rio de Janeiro / Brasil \\ annabasevi@gmail.com
}

Resumo: A obra de Primo Levi representa diversas formas do desterro - o exílio "absoluto", o nóstos, a diáspora - que moldam a própria estrutura narrativa. A condição do exilado parece assumir a função metafórica de uma experiência histórica e humana, função que Claudio Magris atribui ao mundo judaico e que, ao mesmo tempo, se insere entre os tópicos da literatura do séc. XX. Nestes contextos distintos de exílio, o artigo evidencia as formas de descrever a paisagem estrangeira capazes de trazer à tona marcas estilísticas e narrativas do autor, em diálogo com a literatura clássica de Homero e Ovídio, e com as representações bíblicas. Esta proposta de leitura confirma a ligação estreita, presente em Levi, entre a condição de estrangeiro e a condição do ser humano no estado de exceção da Europa dominada pelo nazismo.

Palavras-Chave: exílio; literatura; Primo Levi.

Abstract: Primo Levi's work portrays several exile forms: the "absolute" exile, the nóstos, the diaspora. These are kinds of exile that help shaping the narrative structure itself. The exiled seems to assume a metaphoric function for both historical and human condition. According to Claudio Magris, this function can be, at the same time, related to the Jewish world and inserted among literary topics from the 20th century. Drawing on those distinct contexts of exile, this article shows how the descriptions of

${ }^{1}$ Pós-Doutoranda FAPERJ-nota 10. 
the foreign landscape are evidence to the author's stylistic and narrative features, in connection with the classic literature of Homer and Ovid, and with the biblical representations. This analysis proposal confirms the close connection, present in Levi, between the status of foreigner and the condition of the human being in the state of exception of Europe dominated by Nazism.

Keywords: exile; literature; Primo Levi.

Na obra do escritor italiano Primo Levi (1919-1987) o tema do exílio apresenta-se sob diferentes facetas, provindo tanto da experiência autobiográfica quanto da reconstrução narrativa das aventuras e personagens.

Em sua primeira e mais conhecida narrativa, É isto um homem? (Se questo è un uomo, 1947), a condição exílica encarna-se primeiramente na trágica vivência dos judeus deportados a Auschwitz, onde o próprio autor permanecera entre 1944 e 1945. Dentro do perímetro concentracionário, o exílio configura-se como absoluto, incluindo o exílio linguístico, sendo o idioma italiano extremamente minoritário.

A trégua, escrito em 1963 e que proporciona ao escritor o sucesso de público e de crítica, narra a viagem de retorno do sobrevivente, um verdadeiro nóstos do século XX. Uma vez liberto pelo exército soviético, a viagem durou nove meses, devido às precárias condições de muitas linhas de trem bombardeadas e à caótica gestão dos próprios soviéticos. Esse trajeto percorrido por Levi inspirará o percurso dos combatentes judeus, protagonistas de Se não agora, quando?, romance escrito em 1982. A trama acompanha o itinerário de um grupo de judeus, organizados na resistência armada contra o exército alemão. Sua viagem representa um movimento de saída das terras russas em busca de uma nova pátria, abandonando aquele mundo judaico oriental de língua iídiche extinto pela perseguição.

Para Levi, nascido na cidade de Turim, no centro de uma paisagem pré-alpina e ao mesmo tempo próxima ao Mediterrâneo, o abandono forçado de sua terra acontece em 1943, num trem de carga rumo a Auschwitz, o maior campo de extermínio da Alemanha nazista, situado na Polônia. A passagem da fronteira com a Áustria ressoa no silêncio solene e cortante dos exilados trancados no vagão, como narrado em $E^{\prime}$ isto um homem?: 
O trem viajava devagar, com longas e enervantes paradas. Pelas frestas, vimos desfilar as altas e pálidas rochas do Vale do Adige, os últimos nomes de cidade italianas. Cruzamos a fronteira, o Passo do Brennero, às doze horas do segundo dia; todos levantaram, mas ninguém disse nada. Eu tinha no coração o pensamento do retorno e, cruelmente, imaginava qual seria a alegria sobre-humana dessa nova passagem, com as portas dos vagões escancaradas (ninguém pensaria em fugir) e os primeiros nomes italianos... (LEVI, 1988, p. 16).

A perda de pontos de referências geográficos inicia-se na passagem da fronteira, quando é possível ainda supor um retorno, mas onde já age a nostalgia. $\mathrm{O}$ aproximar-se do mundo nórdico, gelado e plano, aponta para o exílio.

Pela fresta, alguns nomes conhecidos e outros estranhos de cidades austríacas, Salzburg, Viena; depois, tchecas; por fim, polonesas. $\mathrm{Na}$ noite do quarto dia, o frio ficou mais pungente; o trem corria entre escuros pinheirais sem fim, sempre subindo. A neve era alta. Deveríamos estar numa linha secundária, pois as estações eram pequenas e quase desertas. Ninguém tentava mais comunicar-se com o mundo externo; sentíamo-nos "no outro lado". Houve uma longa parada na campina aberta; logo a marcha recomeçou lenta, lentíssima, até que o comboio parou definitivamente, no meio da noite, numa planície escura e silenciosa. (LEVI, 1988, p. 17).

O silêncio externo da planície e o vagão trancado funcionam como molduras de um banimento duplo, da terra natal e do mundo dos vivos. Já podemos vislumbrar, entre os aspectos da paisagem, a planície parecida a um deserto como marca geográfica do exílio narrado, que se tornará paradigmática e que aqui determina a descida ao mundo dos não vivos.

No caso dos dois romances, A trégua e Se não agora, quando?, a visualização do trajeto por meio de um mapa reforça a leitura no que diz respeito às distâncias percorridas, ao estranhamento do estrangeiro (o italiano Levi) e à peculiaridade da geografia cultural de um mundo em diáspora (o judaísmo do leste europeu). Na edição de $A$ trégua, o mapa evidencia o itinerário da longa viagem de regresso de Auschwitz enfrentada por Levi através do continente em ruínas. Entre demoradas esperas e transportes precários, entre a persistência da fome e do frio, a terra procurada é a cidade de Turim, o solo itálico avistado assim que o trem ultrapassa a última fronteira austríaco-italiana. Mas o que constitui 
uma aventura anômala é, muito antes, o desvio para leste e depois, com grande surpresa dos viajantes, para norte da Bielorrússia, enquanto a meta encontra-se na direção exatamente oposta.

\section{FIGURA 1 - Mapa de A trégua}

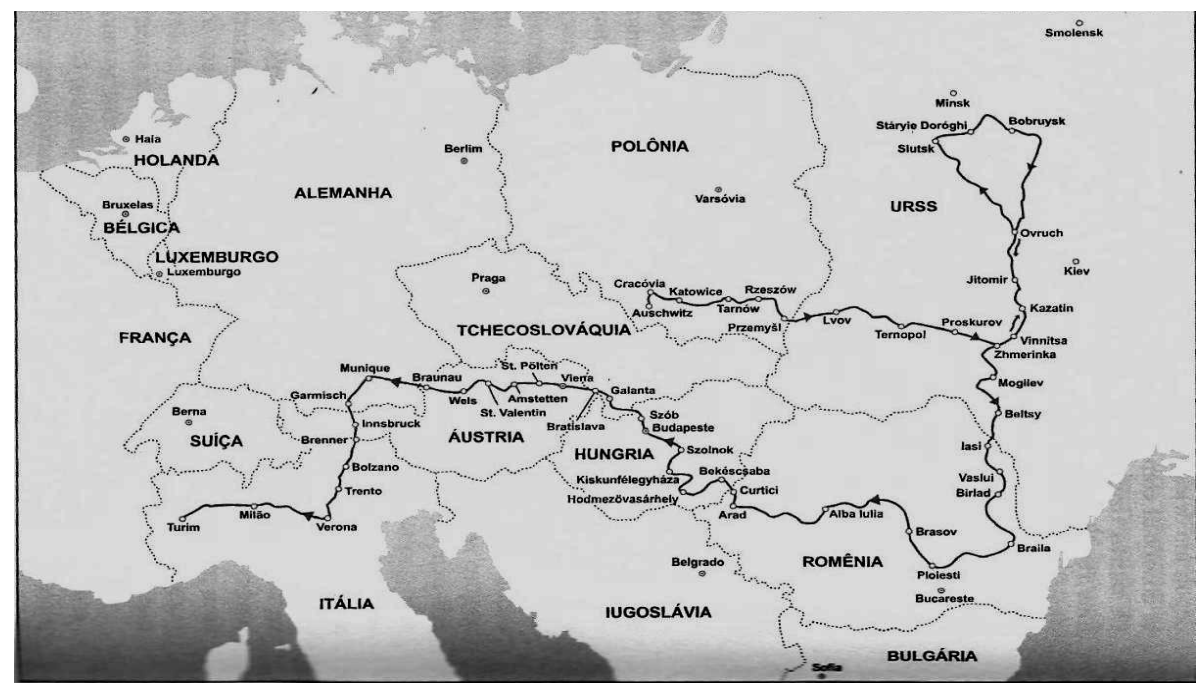

Fonte: LEVI, 1997, p. 208 (edição da Companhia das Letras).

Este trajeto inspira e corresponde em parte ao percurso dos combatentes judeus do romance Se não agora, quando?, cujo rumo não é a própria pátria, já perdida, mas a Palestina. O grupo de homens e mulheres que tentam construir seu destino, escapando ao extermínio, se desloca a partir da Rússia para chegar à Itália, país acolhedor aos seus olhos, possível ponto de chegada ou de parada provisória. O percurso dos protagonistas envolve as regiões da Europa Central, a Polônia, a Áustria e a Alemanha, como na viagem de Levi, porém passando ao norte da fronteira tcheca. A verdadeira diferença, todavia, diz respeito ao desenho e ao significado da trajetória: desviado no primeiro caso, linear no segundo. 
FIGURA 2 - Mapa interno ao romance Se non ora, quando?

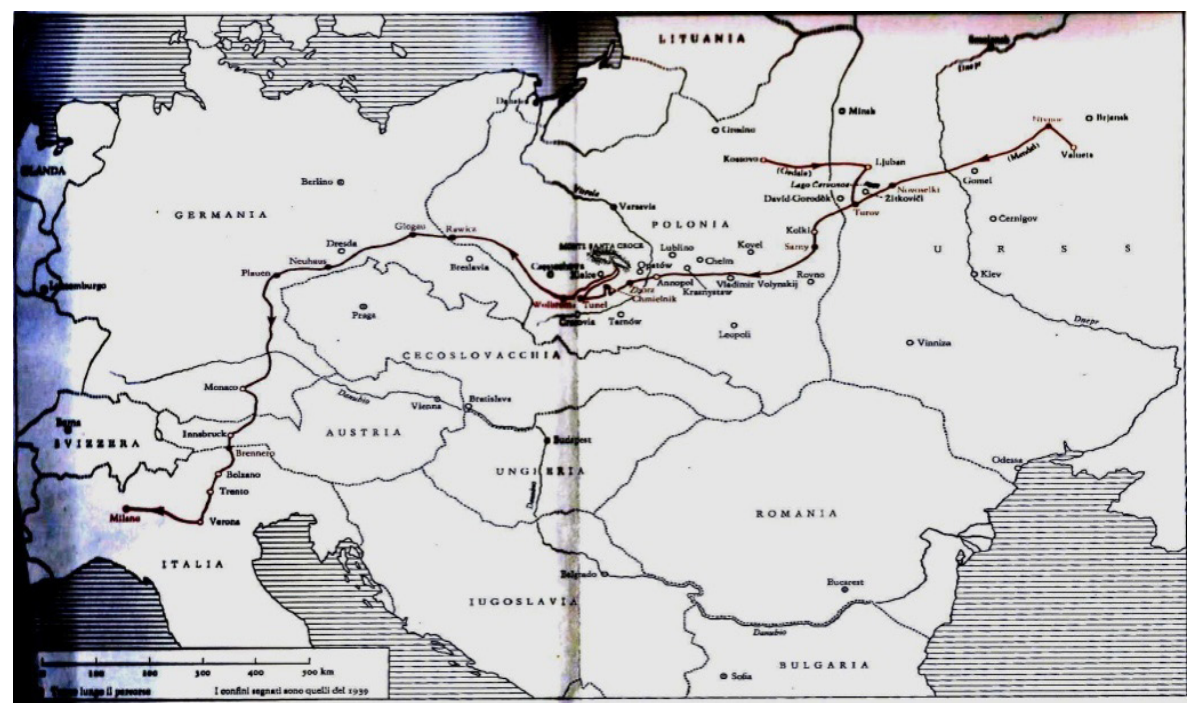

Fonte: LEVI, 1982, p. 2 (edição da Einaudi).

De fato, Mendel, o relojoeiro russo, e seus companheiros deslocam-se na direção sudoeste até a Alemanha, para em seguida descer até Milão, com apenas pequenos desvios logísticos durante a jornada. Sua viagem é só de ida, e a Itália representa apenas uma etapa possível.

Cesare Segre sugere uma interpretação do romance como uma tentativa original de mapeamento da catástrofe do século XX:

O mapa de Se não agora, quando? possui ainda uma implicação simbólica. Se percorrermos o mapa ao avesso, do campo de acolhimento perto de Milão até Valuets (URSS), serão tocadas as áreas mais importantes do judaísmo oriental, da Ostjudentum (ashkenazi) [...] E Se não agora, quando? é, também, um canto fúnebre desta civilização hebraica oriental, terminada nos campos de concentração nazistas. (SEGRE, 1997, p. 95, tradução nossa).

Se é verdade, como podemos ler no ensaio de Carlinda F. P. Nuñez (2010, p. 81), que "a categoria ficcional do espaço constitui o eixo dinamizador de todo sistema literário", no caso dos romances em questão a "parceria inusitada" entre geografia e literatura ratifica tanto no nível literal quanto no nível figurativo o uso dos empréstimos lexicais 
provenientes das ciências do território (p. 80). Palavras como fronteira, horizontes, trajeto, direção, mapa testemunham esta dupla função e carregam estratificações de significados pertencentes aos dois campos, geográfico e literário (p. 90), inevitavelmente fundidos ao falarmos das duas narrativas. Desta maneira, as planícies intermináveis, os pântanos e o predomínio da lama durante o degelo caracterizam paisagens polonesas e russas, atravessadas nos dois romances - e já encontradas em Auschwitz - assinalando uma geografia interna e externa inóspita, quando privada de centros habitados e de acolhimento humano. De forma oposta, aparecem espaços sobrecarregados de gente (como também no Lager) em cidades, feiras ou pontos de atendimento a refugiados. O leitor viaja entre horizontes de solidão e de convivência grupal intensa, através de um tempo suspenso após a catástrofe (A trégua) ou tempos transitórios na busca urgente de uma nova morada (Se não agora, quando?).

A associação emblemática de deserto-planície-exílio caracteriza toda a prosa de Levi, desde $\dot{E}$ isto um homem? até $A$ chave estrela ( $L a$ chiave a stella, 1978). Em Auschwitz, o tempo parece imóvel tanto quanto o espaço parece uniforme e monótono, os dias iguais e sem perspectivas, o horizonte engole a terra e o céu, ambos de igual cor cinza. A representação do desamparo atribui à planície invernal das terras eslavas o papel da geografia simbólica do indivíduo afastado ou exilado.

No entanto, o deserto como forma paisagística e mítica do desterro remonta à narração bíblica do Êxodo. Os hebreus, conduzidos por Moisés na longa viagem do Egito à Terra de Canaã, permanecem no deserto durante um período de quarenta anos. O deserto apresentase como lugar do exílio, embora um exílio diferente da escravidão sofrida na terra do Faraó e como espaço de transição. A paisagem do deserto é um espaço com uma alta carga alegórica, "onde são banidos os expulsos, os rejeitados, os marginalizados" (ABÉCASSIS, 1987, p. 95, tradução nossa), "o lugar dos desterrados" (ABÉCASSIS, 1987, p. 109, tradução nossa $)^{3}$ e que, ao mesmo tempo, propicia "um aprendizado da condição humana" (ABÉCASSIS, 1987, p. 109, tradução nossa). ${ }^{4}$ Neste caso, as vastas e desoladas planícies nórdicas operam da

\footnotetext{
2 “[...] où l'on chasse les reprouvés, les rejetés, les marginaux".

3 “"...] le lieu des déplacés".

4 “[...] un apprentissage de la condition humaine".
} 
mesma forma, especialmente para um italiano originário de uma terra situada entre os Alpes e o mar.

A significação negativa de uma antipaisagem, que nada é senão a paisagem aos antípodas do mundo mediterrâneo, retorna em tempos recentes em Claudio Magris, na descrição da estepe danubiana, em terra romena: "lugar de desolação e exílio, verões áridos e gélidos invernos, horizonte sem fim" (MAGRIS, 2006, p. 456, tradução nossa). Se uma paisagem apresenta características próprias, ao mesmo tempo o exílio molda o sentimento de recepção da mesma, como ocorre quando "a potência das palavras ainda hoje projeta sobre o Mar Negro a imagem de um deserto equóreo, de um grande brejo opressivo, um lugar de exílio, invernos e solidões" (p. 449). As palavras às quais Magris se refere e que ressoam com seu poder evocativo provêm da longínqua Tomis (hoje Constança, na atual Romênia), onde o poeta Ovídio passou seus últimos nove anos, banido pelo imperador Augusto. Portanto uma das mais antigas descrições desta geografia exílica está lavrada nas Cartas Pônticas:

\begin{abstract}
Jazo, nada obstante, abandonado nas areias da extremidade do orbe, onde a terra ostenta perpétuas neves. Aqui o campo não produz frutos nem doces racemos; não reverdejam salgueiros nas ribeiras, nem robles nas montanhas. O pélago não merece mais louvores que a plaga: suas vagas, privadas de sol, estão sempre intumescidas pelo furor dos ventos. Para qualquer direção que se olhe, estendem-se planícies sem cultivo e terras desertas que ninguém reivindica. (OVÍDIO, 2009, livro 1, 3, 49-56).
\end{abstract}

Aprisionado em seu cruel destino, o escritor de Tristia parece atribuir à região descrita - deserto, neve, vento, falta de uva, ${ }^{5}$ de frutos, de sol - a marca indelével do exílio e de terra antimediterrânea por excelência.

Para Levi, durante a viagem de regresso ao longo das linhas de trem devastadas e após a catástrofe da guerra, a percepção do espaço que separava a almejada Itália da Polônia ou da Romênia talvez fosse próxima à de Ovídio, apesar do desenvolvimento dos transportes. E Levi, sobre a mesma terra do banimento ovidiano, escreveu: "Atravessando planícies

\footnotetext{
${ }^{5}$ A presença da árvore da uva denotava para Ulisses a civilização do trigo e do vinho: "Para os gregos, o próprio do homem, o que o define como tal, é o fato de comer pão e beber vinho, ter um certo tipo de alimentação e reconhecer as leis da hospitalidade, acolhendo o estrangeiro em vez de devorá-lo" (VERNANT, 2013, p. 100).
} 
ainda estivais, atravessando pequenas cidades e vilarejos, cujos nomes soavam bárbaros (Ciurea, Scantea, Valsui, Piscu, Braila, Pogoanele), seguimos ainda por vários dias para o Sul, em minúsculas etapas" (LEVI, 1997, p. 194). O adjetivo bárbaros é escolhido para designar, mesmo sob o sol do verão, os nomes estrangeiros, tão "bárbaros" quanto devem ter soado aos ouvidos do poeta latino. Contudo, a língua romena também aproxima o viajante à pátria, mais do que o idioma de origem fino-úgrica. Poucas páginas depois, a superação da fronteira húngara radicaliza o desamparo e relativiza o impacto anterior de familiaridade com o idioma romeno:

Se na Romênia eu experimentara um delicado prazer filológico ao degustar alguns nomes como Galati, Alba Iulia, Turnu Severin, na primeira entrada na Hungria tropeçamos, ao contrário, em Bekéscsaba, a que se seguiam Hódmezövasárhely e Kiskunfélegyháza. A planície magiar estava impregnada de água, o céu, plúmbeo. (LEVI, 1997, p. 200).

Observamos a reiteração dos elementos "planície”, terra impregnada de água, "céu plúmbeo", atrelados desta vez aos termos húngaros, enigmáticos e incompreensíveis, que restituem ao viajante os sentimentos de desnorteamento após a passageira sensação saborosa oferecida pelas palavras de origem latina (Alba Julia etc.). A viagem de $A$ trégua apresenta um movimento irregular de distanciamento e aproximação à terra natal, de constante alternância entre os sentimentos de estranhamento, desespero e esperança; trata-se de um périplo interior, além de geográfico. As etapas emocionais de um itinerário nada linear são determinadas pela presença de um idioma conhecido ou desconhecido, pela oportunidade de narrar as peripécias e ser escutado ou não encontrar ouvintes, pela maior ou menor familiaridade com as pessoas e com os hábitos encontrados. De resto, a própria viagem de Ulisses é hoje estudada e lida "como uma trajetória alegórica entre a perda inicial de rumo, a desorientação funesta sobre 'o mar sem caminhos', como diz Homero, e a volta a Ítaca, à ordem familiar e política" (GAGNEBIN, 2006, p. 13). Não se trata de investir a narrativa de Levi de significados apenas alegóricos que desfoquem o projeto testemunhal, mas sublinhar elementos de reforço da temática do exílio, envolvendo a paisagem descrita em moldes literários. 
Decerto, para os desterrados do Leste a reconstituição de um lar ainda estava longe, quando "se deparavam cada vez com maior frequência com uma lama distinta, permanente, dona dos lugares, que vinha da terra e não do céu" (LEVI, 1999, p. 52), ou nos grandes espaços vazios onde o horizonte que os cercava "jamais fora tão vasto, durante a viagem inteira. Vasto e triste, empapado com intenso cheiro funéreo dos juncos" (LEVI, 1999, p. 54). A aparência hostil radicaliza-se nas proximidades ameaçadoras do inverno, quando o gelo consolida a lama, ou em tempo de degelo por vezes mais duro do que o inverno (LEVI, 1999). Esta paisagem, como foi acima dito, é a mesma que impressiona e angustia o sobrevivente, nostálgico dos cumes alpinos e de um céu mais luminoso:

Certa feita, experimentamos sair do retângulo das casernas e caminhar pela planície, recolhendo ervas comestíveis: mas, passada meia hora de caminhada, parecia que estávamos no mar, no centro do horizonte, sem árvore, colina, ou casa para escolher como meta. Para nós, italianos, habituados às montanhas, às colinas e à planície cheia de presenças humanas, o espaço russo, imenso, heroico, dava vertigem e sobrecarregava o coração de lembranças dolorosas. (LEVI, 1999, p. 126-127).

Uma paisagem estrangeira, esta, que não hospeda, não acolhe, mas remete à nostalgia de panoramas familiares, a uma Heimweh estendida à geografia.

A paisagem, segundo Nuñez (2010, p. 87), é "uma instância de apreensão holística do humano e, ao mesmo tempo, uma mímesis em que processos de estetização e ficcionalidade se encontram esplendidamente concentrados". Por esta razão, nas duas narrativas (e inclusive em Se não agora, quando?), o exílio assume tantas vezes as cores da neve e da lama, e seu sentimento correspondente é de vertiginosa perda diante da desesperadora vastidão de planícies monótonas e intermináveis. $\mathrm{O}$ panorama confortante dos Alpes induz o autor à fixação da oposição literal e metafórica entre planície/deserto e montanha, no plano do imaginário textual. Lembramos que, ao avistar a montanha do purgatório, o Ulisses dantesco supera os limites de Gibraltar antes de se lançar ao naufrágio decretado pela vontade divina. 
Os dois títulos, La tregua e Se non ora, quando?, remetem a uma dimensão temporal, peculiar para cada viagem, ${ }^{6}$ embora para o segundo título possa se notar uma alteração da pergunta mais comum do exilado, “onde?", a qual por sua vez "traduz a impotência de ter uma própria terra” (DUFOURMANTELLE, 2003, p. 19).

Independentemente da diferença entre nível mítico e histórico, se já acontecera em 1492 que "o exilio da Torá [...] adquiriu significado pleno com o exílio histórico do povo judeu” (SCHOLEM, 1978, p. 87), a ocupação nazista da Europa oriental reeditou novamente uma diáspora, moderna, um êxodo de refugiados e emigrantes em fuga do extermínio.

A narração de $A$ trégua começa exatamente onde $E$ isto um homem? termina, com a chegada do exército soviético representando o mundo livre externo ao Campo, na primeira cena descrita em A trégua sob o evocativo título "O degelo":

A primeira patrulha russa pôde ser vista do campo por volta de meio-dia de 27 de janeiro de 1945. Charles e eu fomos os primeiros a avistá-la: estávamos transportando para a vala comum o corpo de Sómogyi, o primeiro morto entre os nossos companheiros de quarto. Reviramos a padiola na neve infecta, pois a vala já estava cheia, e outra sepultura não era possível: Charles tirou o boné para saudar os vivos e os mortos. (LEVI, 1997, p. 9).

No entanto, o regresso do exilado raramente restaura as identificações de outrora. A terra que o viajante reencontra é a mesma e, contudo, é outra, as coisas perdidas afloram então desta névoa que é a ilusão do retorno como aparências, semblantes, vestígios (PRETE, 1992, p. 26, tradução nossa). Nesta perspectiva, Vladimir Jankélévitch (1992, p. 130-152 passim) estabelece uma distinção entre nóstos fechado - através do qual o exilado alcança sua meta e o círculo se fecha - e o nóstos aberto, quando a nostalgia não se apazigua na reconquista da pátria perdida. Este estado permanente de desejo por algo inalcançável

\footnotetext{
${ }^{6}$ A questão dos títulos não é secundária, mas precisaria de mais espaço para ser detalhada. Limitamo-nos a assinalar que o título Se não agora, quando? provém de um trecho bíblico: "Se eu não for por mim, quem será? Se sou só por mim, o que é que eu sou? E se não for agora, quando?” (TALMUD, Pirkei Avot, 1:2).
} 
aponta para uma condição psíquico-existencial, senão metafísica, do ser humano. Mas podemos considerá-lo também adequado às amarguras da anábase do sobrevivente.

No ensaio sobre a nostalgia, Jankélévitch analisa o episódio emblemático da epopeia homérica na qual Ulisses alcança sua ilha e não a reconhece. Portanto, sua chegada é a chegada de um estrangeiro: ele se vê destinado a outra peregrinação e se desespera perante uma Ítaca disfarçada; e quando descobre estar em sua pátria é obrigado a se apresentar como estrangeiro. Os sentimentos de desamparo e de estranhamento, que parecem estender o exílio para além do suportável, introduzem uma fratura no alívio do nóstos, anunciada pela cena em que "a terra natal se veste de terra estrangeira" (JANKÉLÉVITCH, 1992, p. 146). Neste sentido, algo impede que o nóstos se feche totalmente, e a trama de sua circularidade apresenta pontos rasgados.

Ao tomar a volta de Ulisses como paradigma, Jeanne Marie Gagnebin (2006, p. 110) comenta que "depois da Segunda Guerra Mundial não se reconhece mais o forasteiro pela cicatriz da infância-ele continua estrangeiro a si mesmo e a seus familiares, em seu próprio país".

Nas últimas linhas de $A$ trégua irrompe um pesadelo, o do revenant que sonha estar sonhando com um regresso imaginário, constatando no final a triste realidade do aprisionamento. O sonho é recorrente, e a desilusão envolvida sempre cortante:

É um sonho dentro de outro sonho, plural nos particulares, único na substância. Estou à mesa com a família, ou com amigos, ou no trabalho, ou no campo verdejante [...] pouco a pouco ou brutalmente, todas as vezes de forma diferente, tudo desmorona e se desfaz ao meu redor [...] Tudo agora se tornou caos: estou só no centro de um nada, turvo e cinzento. E, de repente, sei o que isso significa, e sei também que sempre soube disso: estou de novo no Lager, e nada era verdadeiro fora do Lager [...]. (LEVI, 1997, p. 212-213).

O significado da longa viagem que representou uma trégua entre a saída do Campo e a chegada em pátria é revelado, pois o final do pesadelo restaura a condição de prisioneiro: 
Agora esse sonho interno, o sonho de paz, terminou, e no sonho externo, que prossegue gélido, ouço ressoar uma voz, bastante conhecida; uma única palavra, não imperiosa, aliás breve e obediente. É o comando do amanhecer em Auschwitz, uma palavra estrangeira, temida e esperada: levantem, "Wstavach". (LEVI, 1997, p. 212-213).

Trata-se da expressão polonesa gritada pelos Kapos em todas as frias madrugadas da vida do Lager. O sonho e o livro concluem-se com esta palavra estrangeira e ameaçadora que imprime ao movimento do texto uma guinada improvisada de conjunção ao incipit. Despertar e Lager voltam entrelaçados e em tensão: o "despertar" (do título do último capítulo e do correspondente vocábulo polonês) é especular o início, onde as imagens concentracionárias estavam descritas sob o evocativo título de um despertar climático, "O degelo", configurando uma circularidade narrativa. De fato, este despertar final preenche-se de um duplo sentido: o retorno do inferno significa o retornar do narrador de um lugar, isto é a viagem de subida ao mundo dos vivos, a saída do Lager; mas o "retorno do inferno" pode significar também o fato de que o inferno retorna, embora sob forma onírica, isto é, o regresso do sobrevivente ao Lager. O nóstos demonstra brechas em sua circularidade fechada e a estrutura narrativa de $A$ trégua consegue dar forma a esta ideia. $\mathrm{O}$ fim do pesadelo de Auschwitz manifesta-se em sua veste ilusória: nenhum retorno restaura um passado imaculado, a experiência aplica suas marcas ao presente. A palavra Wstavac irrompe no começar de um dia, projetando-nos tanto ao começo do livro quanto mais longe ainda, ao início de tudo, no meio do Caos: às geladas e traiçoeiras auroras do Campo. Desta forma, o sonho sugere de repente uma chave de leitura do texto a partir de seu final.

O romance Se não agora, quando? parece constituir uma representação das formas de sobrevivência ao extermínio nazista mais sucedidas: resistência e fuga através da luta ativa. Ao mesmo tempo corresponde à bifurcação dos dois destinos possíveis para os combatentes de toda Europa: a captura e a deportação de um lado, como aconteceu com Levi, ou a continuação da luta clandestina. A atitude desses jovens, que se percebem donos de seu destino, reaparece no discurso da personagem Line, em resposta a quem os classifica como displaced persons: 


\begin{abstract}
"Nós não somos DP”, disse Line. "Nós tínhamos uma pátria, e não é nossa culpa se não temos mais; construiremos outra. Está adiante de nós e não atrás. [...] Nós não somos DP, somos resistentes, e não apenas no nome. Temos construído nosso futuro com nossas mãos". (LEVI, 1982, p. 244, tradução nossa). ${ }^{7}$
\end{abstract}

Resgata-se desta forma a história de uma capacidade combativa judaica "anestesiada por séculos de não violência, de docilidade forçada, de chantagens sofridas" (SEGRE, 1997, p. 95). Mulheres e homens pacíficos e simples, artesãos, sobreviventes dos diversos massacres disseminados por suas terras, armaram-se para sobreviver:

Estavam cansados, sujos e pobres, mas não derrotados; filhos de comerciantes, alfaiates, rabinos e cantores, tinham se equipado de armas tiradas aos alemães, haviam conquistado o direito de vestir aqueles uniformes rasgados e sem patentes, e tinham saboreado várias vezes o alimento amargo do matar. (LEVI, 1999, p. 161).

A viagem do grupo conduzido pelo comandante Gedale procede também rumo a uma reconquista identitária, enriquecendo-a de experiências renovadoras, desconhecidas anteriormente pelos humildes e perseguidos habitantes dos shtetl - as aldeias do leste europeu. Agora, eles "estavam alegres e ferozes, como animais a quem se abre a jaula, como escravos rebelados prontos para a vingança" (LEVI, 1999, p. 127).

O leitmotiv da sobrevivência através da luta encontra-se já esboçado em A trégua, na descrição de uma personagem soviética, "uma garota do campo, rápida, ingênua, um pouco coquete, muito vivaz", sem grande cultura, nem "particularmente séria", mas na qual "sentiase agir a mesma virtude, a mesma dignidade dos seus companheirosamigos-namorados, a dignidade de quem trabalha e sabe por que, de quem combate e sabe ter razão, de quem tem a vida diante de si" (LEVI, 1997, p. 75). Como se pode notar, a dignidade está intimamente ligada às possibilidades de escolha num contexto de liberdade: o trabalho útil e valioso versus a esmagadora fadiga dos escravos, a resistência ativa, a perspectiva de um futuro. Nos combatentes judeus vislumbra-se mais claramente o resgate narrativo em prol dos sobreviventes impossibilitados

\footnotetext{
${ }^{7} \mathrm{Na}$ tradução da edição brasileira a última frase da citação é colocada no futuro “Construiremos o nosso futuro com as nossas mãos” (LEVI, 1999, p. 288).
} 
de reagir: Mendel, Line, Gedale mostram o potencial de ação, em muitos casos apagado pela violência da aniquilação.

Paola Valabrega observa o tratamento dado a um nível lexical e estilístico, através do uso de verbos de deslocamento que indicam a ação principal das personagens: andar, ir, seguir, retomar o caminho, continuar na estrada. Verbos que "marcam o constante passar do tempo que se ajusta à longa marcha [...] através da Europa" (VALABREGA, 1997, p. 267, tradução nossa). Ao longo de uma trajetória que só pode seguir em frente, a esperança da reconstrução de uma moradia projeta-se numa geografia nova e distante da terra de origem: "As personagens de Levi buscam no futuro sua própria Heimat”' (VALABREGA, 1997, p. 270).

$\mathrm{O}$ escritor parte de fato de elementos da tradição judaica para atingir temas universais, como destaca Segre:

No pano de fundo judaico de Se não agora, quando? encontramse a maioria dos componentes ideológicos, assim como ideativos, do romance. Foi o Levi escritor quem identificou neste núcleo tão específico uma potencial universalidade. [...] as cordas tocadas pela nostalgia, pelo desespero ou pelos sonhos de resgate são cordas universais. [...] A casa perdida, a pátria perdida é um dos Leitmotiv do romance. (SEGRE, 1997, p. 103, tradução nossa).

O crítico acrescenta que os temas da guerra contínua e da perda das raízes transformam as personagens de Levi em representantes de uma humanidade privada de amparo, tornando-as "peregrinos misteriosos que, desde não se sabe quando e nem de onde, caminham rumo a uma meta desconhecida mesmo por eles: testemunhas e vítimas do mal, são detentores de uma sabedoria que ninguém quer aprender" (SEGRE, 1997, p. 104). A especificidade histórico-cultural do exílio judaico, portanto, parece detectar de forma aguda um mal-estar mais abrangente, a condição trágica do ser humano. Segundo Magris (1977, p. 133, tradução nossa), escritores como Joseph Roth, Singer ou Kafka encarnam a função de "reveladores e catalisadores de uma situação geral que, em seu drama, afirmou-se antecipadamente, em toda sua evidência e tragédia, como se tivesse entrado em contato com um reagente ou um azul de tornassol". Afinal, o exílio judaico, explica Magris, encena "a metáfora de uma condição histórica e existencial que vê o indivíduo como um exilado da plenitude e da totalidade da verdadeira vida" (p. 313). O exílio, conhecido por muitos escritores e pensadores na década de 1940, impulsionou 
de fato uma reflexão moderna sobre o ser humano e ao mesmo tempo confirmou um tema da tradição.

O exílio revela-se em toda sua extensão emocional quando o refugiado se sente estrangeiro pela perda definitiva do ponto de origem: "Onde está a minha casa? Não está em lugar nenhum. Está na mochila que carrego nas costas" (LEVI, 1999, p. 237). À fronteira perdida opõe-se a multiplicação de fronteiras a serem atravessadas. Assim, nos deparamos com uma incógnita: qual será a última, se é que haverá uma final? Pois como afirmava o escritor Joseph Roth (1985, p. 18): "Os judeus orientais não têm pátria em lugar nenhum, mas túmulos em cada cemitério". ${ }^{8}$ Roth (apud MAGRIS, 1977, p. 8), ainda, dá voz ao desterro com a imagem de uma sepultura nômade: "Quem sepultar seu pai em terra estrangeira [...] tem direito de cidadania naquela terra alheia, se sente em sua casa como se possuísse ali um terreno".

Similarmente, o sentimento de perda e luto acompanha as personagens de Se não agora, quando?:

Para os judeus a saudade de suas casas não era uma esperança mas um desespero, sepulto até então debaixo de dores mais urgentes e graves, porém latente. As casas não existiam mais: tinham sido destruídas, incendiadas pela guerra ou pelo massacre, ensanguentadas por esquadrões de caçadores de homens; casastúmulos, nas quais era melhor não pensar, casas de cinzas. Por que continuar vivendo, por que combater? Em prol de que casa, de que pátria, de que futuro? (LEVI, 1999, p. 114-115).

De acordo com Derrida (2003, p. 79), o estrangeiro pode ser definido tanto pelo lugar de nascimento como pela experiência da morte e do luto: "as 'pessoas deslocadas', os exilados, os deportados, os expulsos, os desenraizados, os nômades [...] gostariam de voltar, pelo menos em peregrinação, aos lugares em que seus mortos inumados têm sua última morada". Ao abordar a morte de Édipo e o luto impossível de Antígona, em Sófocles, o filósofo esclarece que a descrição do estrangeiro estruturase em torno de ausências: "estrangeiro de ter vindo morrer em terra estrangeira, estrangeiro de ser enterrado num lugar secreto, estrangeiro de ser enterrado sem sepultura visível, estrangeiro de não poder ser chorado como se deve, normalmente, pelos seus enlutados" (p. 101).

${ }^{8}$ Título original de Joseph Roth: Juden auf Wanderschaft. 
Se, para Roth, o lugar da morte de um ente querido passa a constituir uma nova pátria, e a presença do vínculo afetivo age como selecionador de um território, em Se não agora, quando? o enraizamento também se tornaria possível: o nascimento de uma criança, parida por uma mulher do grupo de Mendel, sugere a eleição do solo itálico como alternativa à partida para a Palestina e poderia inaugurar este tipo de vínculo casual, mas "naturalmente" adquirido na viagem. Uma etapa de vida que coincidiria com uma etapa da viagem. O trajeto levaria à escolha, e não vice-versa. A permanência na Itália representa apenas uma hipótese que se abre, todavia, não será possível falar de um fim de viagem para os judeus errantes. A "grandiosa anábase contemporânea" (PAMPALONI apud FERRERO, 2007, p. 105) de Se não agora, quando? tem características próprias e equivale à aliá (o retorno):

Findas as insídias, finda a guerra, a estrada, o sangue e o gelo, morto o satã de Berlim, vazio e vago o mundo, a ser recriado, a ser repovoado, como depois do dilúvio. Em subida, em alegre subida rumo à passagem: subida, aliá, assim se chama o caminho quando se sai do exílio, do profundo, e se sobe rumo à luz. (LEVI, 1999, p. 280).

Diferentemente da forma circular do nóstos grego e do périplo casual de Levi, a viagem de Mendel possui apenas um horizonte à frente por onde avançar, conforme a imagem de uma linha reta. ${ }^{9}$ A trama de Se não agora, quando? interrompe-se numa terra de passagem, e não sabemos se e quem seguirá a viagem. A estrutura narrativa segue, portanto, a trajetória de um percurso aberto para a frente sem destino final. A última cena, porém, põe em cheque a ilusória paz conquistada. No novo dia, quando a cidade estrangeira recomeça sua vida, nasce o filho de Isidor e Rókhele. Todavia, não faltam as contradições do despertar:

Todos ficaram em pé. Mendel e Line abraçaram Isidor, cujos olhos, avermelhados pela vigília, tinham se tornados límpidos. O doutor também saiu [...] se deparou com um colega que avançava com um jornal dobrado e se deteve para discutir com ele. Ao redor dos dois se agruparam outros médicos, freiras, enfermeiras, Mendel também se aproximou, e conseguiu ver que o jornal, constituído

\footnotetext{
${ }^{9}$ Observações sobre as alegorias da forma circular e da linha reta para as tradições, respectivamente, grega e cristão-judaica (Ulisses de Dante) em Lombardi, 2006.
} 
de uma única folha, trazia um título em corpo muito grande, cujo significado não entendeu. Aquele jornal era da terça-feira, 7 de agosto de 1945, e trazia a notícia da primeira bomba atômica lançada sobre Hiroshima. (LEVI, 1999, p. 305).

Enquanto uma parte da humanidade desperta para um novo início, do outro lado do globo outro povo acorda sob um céu negro e funesto, num dia de fim de guerra que reabre o ciclo das catástrofes. Do ponto de vista narrativo, as estruturas de A trégua e Se não agora, quando? apresentam um desenho de viagem oposto, contudo, ambos os desfechos de conclusão do exílio testemunham aspectos contrastantes e remetem ao surgimento de ameaças inerentes à complexa história humana.

\section{Referências}

ABÉCASSIS, A. La pensée juive: v. 1. Du désert au désir. Paris: Librairie générale française (Le Livre de poche), 1987. v. 1.

DERRIDA, J; DUFOUMANTELLE, A. Da hospitalidade. Tradução de Antônio Romane. São Paulo: Escuta, 2003.

FERRERO, E. Primo Levi. La vita, le opere.Torino: Einaudi, 2007.

GAGNEBIN, J. M. Lembrar, escrever, esquecer. São Paulo: Editora 34, 2006.

JANKÉLÉVITCH, V. La nostalgia. In: PRETE, A. Nostalgia. Storia di un sentimento. Milano: Cortina Raffaello, 1992. p. 119-176.

LEVI, P. A tabela periódica. Tradução de Luiz Sérgio Henriques. Rio de Janeiro: Relume-Dumará, 1994.

LEVI, P. A trégua. Tradução de Marco Lucchesi. São Paulo: Companhia das Letras, 1997.

LEVI, P. É isto um homem?. Tradução de Luigi Del Re. Rio de Janeiro: Rocco, 1988.

LEVI, P. La chiave a stella. Torino: Einaudi, 1978.

LEVI, P. La tregua. Torino: Einaudi, 1972.

LEVI, P. Se não agora, quando? . Tradução de Nilson Moulin. São Paulo: Companhia das Letras, 1999. 
LEVI, P. Se non ora, quando?. Torino: Einaudi, 1982.

LEVI, P. Se questo è un uomo. Note di Alberto Cavaglion. Torino: Einaudi, 2012.

LOMBARDI, A. Ulisses: a viagem e a morte. In: CONGRESSO INTERNACIONAL DA ABRALIC, 10., 2006, Rio de Janeiro. Anais... Rio de Janeiro: ABRALIC, 2006. v. 1. p.1-15.

MAGRIS, C. Danubio. Milano: Garzanti, 2006.

MAGRIS, C. Lontano, da dove?. Torino: Einaudi, 1977.

NUÑEZ, F. P. C. Uma Odisseia no espaço: a geografia na literatura. In: CORREA, R. L.; ROSENDHAL, Z. (Org.). Temas e caminhos da geografia cultural. Rio de Janeiro: UERJ, 2010. p. 73-113.

OVÍDIO. Cartas Pônticas. Tradução de Geraldo José Albino. São Paulo: Martins Fontes, 2009.

PRETE, A. L'assedio della lontananza. In: sentimento. Milano: Cortina Raffaello, 1992. p. 9-41.

ROTH, J. Ebrei erranti. Milano: Adelphi, 1985.

SEGRE, C. I romanzi e le poesie. In: FERRERO, E. (Org.). Primo Levi: un' antologia della critica. Torino: Einaudi, 1997. p. 91-116.

VALABREGA, P. Primo Levi e la tradizione ebraico-orientale. In: FERRERO, E. (Org.). Primo Levi: Un'antologia della critica. Torino: Einaudi, 1997. p. 263-288.

VERNANT, J.-P. O universo, os deuses, os homens. Tradução de Rosa Freire d'Aguiar. São Paulo: Companhia das Letras, 2013.

Recebido em: 31 de janeiro de 2018. Aprovado em: 12 de abril de 2018. 